Walter Fonseca 2 Betty R. Kirkwood 3 Aluisio J. D. Barros 4 Chizuru Misago 3 Luciano L. Correia 2 Jose A. M. Flores 5 Sandra C. Fuchs 4 Cesar G. Victora 4

\section{Attendance at day care centers increases the risk of childhood pneumonia among the urban poor in Fortaleza, Brazil 1}

\author{
Práticas relacionadas aos cuidados da criança \\ aumentam o risco de pneumonia nas \\ crianças menores de dois anos em Fortaleza, \\ Brasil 1
}

1 This study was supported with grants from the International Development Research Centre (IDRC, Canada) and the Consel ho Nacional de Desenvolvimento Científico e Tecnológico (CNPq, Brazil).

2 Departamento de Saúde Comunitária, Universidade Federal do Ceará, Rua Barbosa de Freitas $650 / 402$, Fortaleza, CE 60170-020, Brazil.

3 Maternal and Child

Epidemi ology Unit, London School of Hygiene and Tropical Medicine, Keppel Street, London WC1 7HT, U.K. 4 Programa de Mestrado em Epidemiologia, Universidade Federal de Pel otas, C. P. 464, Pel otas, RS,

96100-000, Brazil.

5 Hospital Pediatrico Santo Antonio, Av. Ceará 1549,

Porto Al egre, RS,

90000-000, Brazil.
Abstract We carried out a case-control study to investigate risk factors for childhood pneumonia in two groups of 650 children aged under two years in the city of Fortaleza, Ceará, Brazil. The cases were children recruited at the main pediatric hospital with a radiological diagnosis of pneumonia, and controls were children of the same age group recruited from the neighbourhood of the cases. In this paper we focus on variables related to chil dcare practices. Working mothers, proportion of time the mother had worked since the child was born, and use of day care centers emerged as important risk factors with estimated relative risks of 1.58, 1.76 and 5.22, respectively. Also important were the number of children living in the house and presence of grandparents. However, the presence of siblings under two years and the birth order were not associated with pneumonia. All analysis included adjustment for confounding by income, parents' education, and other risk factors as appropriate. This is the first study from a developing country to identify attendance at day care centers as a risk factor for increased childhood morbidity, in this case pneumonia. This finding is of significant public health importance for countries such as Brazil with growing urban populations and an increasing need by mothers to find work outside the home.

Key words Pneumonia; Morbidity; Child Health; Epidemiology

Resumo Estudou-seo risco de pneumonia nas crianças menores de dois anos na região metropol itana de Fortal eza entre junho/89 e mai o/90. Foram investi gadas as práticas rel acionadas aos cuidados da criança como possíveis fatores de risco de pneumonia. Fatores maternos, ambientais e sócio-econômi cos foram também estudados devido a sua possível relação com as práticas no cuidado da criança. Foi utilizada metodologia de caso-controle, sendo casos as crianças com diagnóstico clínico e radiológi co de pneumonia, e control es aquel as crianças com diferença de idade inferior a dois meses que não a presentassem si ntomas de infecção respi ratória, e que residissem na vizinhança do caso sel ecionado. Razão de "odds" (RO) foi utilizada para estimar os riscos relativos, através de regressão logística condi cional. Os principais fatores de risco encontrados foram a freqüência a creche $(R O=5,2)$, trabal ho da mãe $(R O=1,6)$ e presença dos avós no domicílio $(R O=1,4)$. A idade da mãe, o número de gestações e a aglomeração também esti veram associados com pneumonia.

Palavras-chave Pneumonia; Morbidade; Saúde da Criança; Epidemiologia 


\section{Introduction}

Acute respiratory infections (ARI) are among the leading causes of childhood morbidity and mortality in developing countries, accounting for approximately one-third of the 15 million deaths that occur annually among children under the age of five years (AHRTAG, 1991). The majority $(75 \%)$ of these ARI deaths are due to pneumonia unassociated with measles (WHO, 1989).

Several factors have been postulated for increased risk of ARI among children in developing countries. These include low birthweight, failure to breastfeed and/ or inappropriate weaning practices, malnutrition, indoor air pollution, and other social factors such as family size, short birth intervals, low income and low level of education of the parents, housing and inappropriate child-care practices (Victora et al., 1989). However, evidence regarding the association between any of these factors and pneumonia in children in developing countries is scarce, and case management is still the main current strategy for ARI control.

There is an increasing interest in the importance of care for child survival, growth, and development. Several studies from developing countries suggest an association between poor child care and malnutrition (Engle, 1990) which is known to reduce resistance to diseases and to increase their severity (Chandra, 1991). However, the relationship between factors related to child care and acute lower respiratory infections (ALRI) among children in developing countries has received very little attention (Pelto \& Kendall, 1990). In particular, only two studies could be identified examining the link with childhood pneumonia.

In this paper we present results from a case-control study examining the effect of mother's work and use of day-care facilities and the risk of pneumonia among children. Other factors such as birth order, total number of children, and presence of grandparents at home are al so discussed, since it was possible to relate them to childcare practices.

\section{Methodology}

A case-control study was conducted in Fortaleza, a city of two million people in Northeast Brazil, located at $3^{\circ}$ South in a tropical zone. At the time of the study the infant mortality rate was approximately 90 per thousand (UNICEF, 1989). According to official estimates, over half of the population live in precarious conditions in favelas [or shantytowns]. Respiratory tract infections are the second highest infectious cause of infant death, accounting for $11 \%$ of such deaths (UNICEF, 1989).

\section{J ustification for choice of study design}

Case-control studies were initially used for studying the causality of non-infectious ("rare") diseases. It has been shown that the rare disease assumption is not al ways necessary. In recent years their use has been expanded to practically every type of disease, including common communicable diseases (Kirkwood, 1988; Rodrigues \& Kirkwood, 1990).

The choice of a case-control design rather than a longitudinal design to identify risk factors for pneumonia was based on both ethical and logistic grounds. First, a longitudinal design would require a considerably larger sample size, since the occurrence of pneumonia is relatively rare. For example, a recent study from the Gambia found an incidence rate of 17 episodes per 100 child years (Campbell, 1989). Thus, 100 children would have to be followed for a full year to detect 17 cases of pneumonia. The number of children that would need to be followed for a year (assuming a similar incidence rate) in order to accumulate sufficient cases would make the study both costly and logistically complex.

Second, ethical considerations dictate that children under surveillance should be treated at the first sign that an episode of ARI is progressing to a severe stage. This treatment would therefore interfere with the occurrence of severe pneumonia, making it difficult to study severe pneumonia as the outcome of interest.

Thus, longitudinal studies with early diagnosis and treatment of ARI episodes tend to include a larger proportion of less severe episodes of pneumonia. Therefore, they would not be appropriate for the study of risk factors for severe pneumonia, which is the most common cause of death due to ARI.

In a case-control study, on the other hand, the starting point is a case of pneumonia. This thus avoids the ethical problems inherent to the longitudinal studies, since the disease status of the study individuals is already determined and inclusion in the study does not interfere in any way with the treatment received. In addition, a case-control design has the logistic benefit that it may be based in a health facility. Recruitment of a sufficient number of cases is relatively quick and easy to carry out. 
The disadvantages of the case-control method lie in the careful consideration needed in the design in order to minimize the types of bias that may occur, and in the relatively sophisticated analysis required (Schlesselman, 1982). Consider first selection bias. Health care coverage for the population in this hospital's catchment area is high, and local experience and discussion with hospital staff suggest that a high percentage of the children with pneumonia living in the catchment area are likely to be seen at the outpatient department. Thus, cases recruited from the health facility will be fairly representative of all cases that occur in the neighbourhood and will not represent a major source of selection bias.

\section{Selection of cases}

Cases were children under two years of age seen at the outpatient clinic of the Albert Sabin Pediatric Hospital with a history of respiratory infection. After medical examination, children with suspected pneumonia were submitted to a chest X-ray, and only those presenting a pulmonary infiltrate were included. All X-rays were examined by the same pediatric radiologist. Children were not eligible for the study if they presented with wheezing or had a recent history of aspiration of liquid or a foreign body. Also excluded were children with measles, symptomatic congenital heart disease, congenital malformation, cerebral palsy, cystic fibrosis, or AIDS. Four percent of potential cases were excluded by these criteria.

Mothers (or guardians) of the potential cases were first contacted at the clinic before the child was submitted to an X-ray. At this time they were asked to participate in the study. After the exclusion criteria were applied, detailed information on place of residence was collected. More than $99 \%$ of the houses were located and only one mother refused to allow her child to participate in the study.

\section{Selection of controls}

Controls were children recruited from the neighbourhood of the cases and matched by age group ( 0 to 5, 6 to 11 , and 12 to 23 months). Wide age brackets were chosen to facilitate matching while allowing for a broad age balance, and did not preclude the analysis of risk associated with smaller age intervals. Children were not eligible as controls if they had a respiratory rate above 50 breaths/min for infants or above 40 breaths/ min for older children, or if they had presented symptoms of measles or pertussis in the preceding ten days. Other exclusion criteria applied to case selection were used in the selection of controls. In order to reduce the possibility of selection bias, only children who would attend government services if they were seriously ill were included as controls.

\section{Sample size}

A total of 650 cases and 650 matched controls were recruited from June 1989 to May 1990. This was sufficient for detecting a relative risk of 2 with $90 \%$ power as significant at the $5 \%$ level, if the prevalence of exposure among control subjects ranged from $4 \%$ to $85 \%$.

\section{Data collection}

A questionnaire was administered to the mother of each case and control, or to the child's normal guardian, and included information on a number of potential risk and confounding factors, such as breast-feeding, environmental factors, indoor air pollution, parental smoking, socioeconomic factors, anthropometric status, demographic factors, and child-care practices. Informed consent was obtained from all mothers by the field workers before recruitment, and the confidentiality of the data collected was ensured by use of coded identification for the subjects. Standardized, pre-coded questions were used for most variables. Quality of the information collected by interviewers was assessed by randomly repeating $10 \%$ of the questionnaires. Disagreements were resolved by the principal investigator. The data were entered into an IBM-compatible micro-computer using DbasellI +. Range and consistency checks were carried out for all variables and the data were cleaned and edited using Dbasel II+and SPSS/PC+.

\section{Analysis}

Odds ratios and their 95\% confidence intervals were calculated. Analysis were carried out using Epi Info 5.1 and Egret, taking into account the matching of cases and controls by neighbourhood and age.

McNemar's chi-square test was used for simple dichotomous risk factors, and the odds ratio calculated from the ratio of the discordant 
pairs, that is, the number of pairs for which the case was exposed and its matched controls unexposed, divided by the number of pairs for which the case was unexposed and its control exposed (Kirkwood, 1988). Two-tailed significance tests were used.

For risk factors with several exposure categories, conditional logistic regression was used to examine whether there was a linear trend of increasing risk of pneumonia with increasing level of exposure, and if so, whether there was any evidence of departure from linearity in this trend. Conditional logistic regression was also used to investigate the effect of risk factors, after controlling for potential confounding variables (Rothman, 1986). A stepwise procedure was not used. Rather, selection of variables for inclusion in the model was based on an a priori consideration of a likely link between different variables and on the results of the univariate analyses. Case-control pairs with missing information for the variable were excluded from the analysis. Full details of the methodology employed have been provided elsewhere (Victora et al., 1994; Fonseca et al., 1996).

\section{Results}

Table 1 shows the risks associated with mothers working and with use of day-care facilities. After adjustment for income and level of education of the father and mother, there was a significant linear trend $(p=0.001)$ for work by the mother. Children of mothers working outside the home were at 1.58 times higher risk of having pneumonia $(\mathrm{Cl}=1.21,2.07)$ than children of non-working mothers, while children whose mothers worked at home were at an intermediate risk of $1.22(\mathrm{Cl}=0.77,1.91)$. The proportion of mothers' working time was expressed as the total number of months worked since the child was born divided by the child's age. There was a significant linear trend $(p=0.02)$ with an odds ratio of $1.76(\mathrm{Cl}=1.13,2.73)$ for the highest category, in which mothers had worked more than $75 \%$ of the child's life, compared to the baseline category of mothers who were not working.

Attendance at day-care centers was also associated with increased risk. After adjustment for several socioeconomic variables, use of day-care facilities increased the risk of pneumonia by 5.22 times $(\mathrm{Cl}=2.13,12.79)$ and this was statistically highly significant $(p<0.001)$. The vast majority ( $80 \%$ ) of children attending day-care centers had mothers working outside the home.

Table 1

Work by mother and use of day-care facilities as risk factors for childhood pneumonia.

\begin{tabular}{|c|c|c|c|c|c|c|c|c|c|}
\hline \multirow[t]{3}{*}{ Risk factor } & & & & & & \multicolumn{4}{|c|}{ Odds ratio $(95 \% \mathrm{Cl})$} \\
\hline & & \multicolumn{2}{|c|}{ Cases } & \multicolumn{2}{|c|}{ Controls } & \multicolumn{2}{|c|}{ Unadjusted $* *$} & \multicolumn{2}{|c|}{ Adjusted*** } \\
\hline & & $\mathrm{n}$ & $\%$ & $\mathrm{n}$ & $\%$ & & & & \\
\hline Work by mother & $\begin{array}{l}\text { No } \\
\text { Yes, at home } \\
\text { Yes, outside home } \\
\text { LRT* }^{*} 2 \mathrm{df} \text { ) } \\
\text { (trend, 1df) }\end{array}$ & $\begin{array}{r}395 \\
45 \\
210\end{array}$ & $\begin{array}{r}60.8 \\
6.9 \\
32.3\end{array}$ & $\begin{array}{r}445 \\
40 \\
163\end{array}$ & $\begin{array}{r}68.7 \\
6.2 \\
25.1\end{array}$ & $\begin{array}{r}1.00 \\
1.27 \\
1.52 \\
10.24 \\
10.22\end{array}$ & $\begin{array}{r}0.81-1.97 \\
1.17-1.97 \\
p=0.006 \\
p=0.001\end{array}$ & $\begin{array}{r}1.00 \\
1.22 \\
1.58 \\
11.32 \\
11.30\end{array}$ & $\begin{array}{r}0.77-1.91 \\
1.21-2.07 \\
p=0.003 \\
p<0.001\end{array}$ \\
\hline $\begin{array}{l}\text { Proportion of mother's } \\
\text { working time - } \%\end{array}$ & $\begin{array}{l}\text { None } \\
<25 \% \\
25-74 \% \\
\geq 75 \\
\text { LRT* (3df) }^{*} \text { (trend, 1df) }\end{array}$ & $\begin{array}{r}395 \\
72 \\
120 \\
61\end{array}$ & $\begin{array}{r}61.0 \\
11.1 \\
18.5 \\
9.4\end{array}$ & $\begin{array}{r}445 \\
69 \\
92 \\
42\end{array}$ & $\begin{array}{r}68.7 \\
10.6 \\
14.2 \\
6.5\end{array}$ & $\begin{array}{r}1.00 \\
1.21 \\
1.50 \\
1.74 \\
10.89 \\
4.63\end{array}$ & $\begin{array}{r}0.84-1.75 \\
1.10-2.05 \\
1.12-2.68 \\
p=0.01 \\
p=0.03\end{array}$ & $\begin{array}{r}1.00 \\
1.28 \\
1.55 \\
1.76 \\
11.59 \\
5.60\end{array}$ & $\begin{array}{r}0.88-1.86 \\
1.12-2.14 \\
1.13-2.73 \\
p=0.009 \\
p=0.02\end{array}$ \\
\hline Use of day-care facilities & $\begin{array}{l}\text { No } \\
\text { Yes } \\
\text { LRT* }^{*}(1 d f)\end{array}$ & $\begin{array}{r}619 \\
31\end{array}$ & $\begin{array}{r}95.2 \\
4.8\end{array}$ & $\begin{array}{r}642 \\
8\end{array}$ & $\begin{array}{r}98.8 \\
1.2\end{array}$ & $\begin{array}{r}1.00 \\
4.83 \\
16.45\end{array}$ & $\begin{array}{r}2.01-11.64 \\
p<0.001\end{array}$ & $\begin{array}{r}1.00 \\
5.22 \\
17.24\end{array}$ & $\begin{array}{r}2.13-12.79 \\
p<0.001\end{array}$ \\
\hline
\end{tabular}

* Likelihood ratio test.

** Based on the analysis of matched case-control sets

*** Adjusted for income, education for father and mother. 
Number of children at home as risk factors for childhood pneumonia.

\begin{tabular}{|c|c|c|c|c|c|c|c|c|c|}
\hline \multirow[t]{3}{*}{ Risk factor } & & & & & & \multicolumn{4}{|c|}{ Odds ratio $(95 \% \mathrm{Cl})$} \\
\hline & & \multicolumn{2}{|c|}{ Cases } & \multicolumn{2}{|c|}{ Controls } & \multicolumn{2}{|c|}{ Unadjusted** } & \multicolumn{2}{|c|}{ Adjusted*** } \\
\hline & & $\mathrm{n}$ & $\%$ & $\mathrm{n}$ & $\%$ & & & & \\
\hline $\begin{array}{l}\text { Total number of } \\
\text { children living at home }\end{array}$ & $\begin{array}{l}1-2 \\
3-4 \\
5-6 \\
7+ \\
\text { LRT* (3df) } \\
\text { (trend, 1df) }\end{array}$ & $\begin{array}{r}290 \\
229 \\
88 \\
43\end{array}$ & $\begin{array}{r}44.6 \\
35.2 \\
13.5 \\
6.6\end{array}$ & $\begin{array}{r}333 \\
218 \\
74 \\
25\end{array}$ & $\begin{array}{r}51.2 \\
33.5 \\
11.4 \\
3.9\end{array}$ & $\begin{array}{r}1.00 \\
1.22 \\
1.40 \\
2.17 \\
10.30 \\
9.79\end{array}$ & $\begin{array}{r}0.95-1.58 \\
0.97-2.02 \\
1.23-3.81 \\
p=0.02 \\
p=0.002\end{array}$ & $\begin{array}{l}1.00 \\
1.17 \\
1.39 \\
2.36 \\
8.53 \\
7.52\end{array}$ & $\begin{array}{r}0.90-1.53 \\
0.93-2.10 \\
1.26-4.43 \\
p=0.04 \\
p=0.006\end{array}$ \\
\hline $\begin{array}{l}\text { Number of children } \\
\text { under } 6 \text { years of age } \\
\text { living at home }\end{array}$ & $\begin{array}{l}1 \\
2-3 \\
4+ \\
\text { LRT* (2df) } \\
\text { (trend, 1df) }\end{array}$ & $\begin{array}{r}218 \\
380 \\
52\end{array}$ & $\begin{array}{r}33.5 \\
58.5 \\
8.0\end{array}$ & $\begin{array}{r}275 \\
343 \\
32\end{array}$ & $\begin{array}{r}42.3 \\
52.8 \\
4.9\end{array}$ & $\begin{array}{r}1.00 \\
1.43 \\
2.29 \\
11.55 \\
10.80\end{array}$ & $\begin{array}{r}1.13-1.82 \\
1.36-3.85 \\
p=0.003 \\
p=0.001\end{array}$ & $\begin{array}{l}1.00 \\
1.35 \\
2.05 \\
8.73 \\
8.60\end{array}$ & $\begin{array}{r}1.05-1.75 \\
1.17-3.60 \\
p=0.01 \\
p=0.003\end{array}$ \\
\hline $\begin{array}{l}\text { Number of children } \\
\text { aged } 6 \text { years or more } \\
\text { living at home }\end{array}$ & $\begin{array}{l}\text { None } \\
1-3 \\
4+ \\
\text { LRT* (2df) } \\
\text { (trend, 1df) }\end{array}$ & $\begin{array}{r}316 \\
279 \\
55\end{array}$ & $\begin{array}{r}48.6 \\
43.0 \\
8.5\end{array}$ & $\begin{array}{r}373 \\
237 \\
40\end{array}$ & $\begin{array}{r}57.4 \\
36.5 \\
6.2\end{array}$ & $\begin{array}{r}1.00 \\
1.53 \\
2.11 \\
5.64 \\
10.98\end{array}$ & $\begin{array}{r}1.17-2.00 \\
1.21-3.68 \\
p<0.001 \\
p<0.001\end{array}$ & $\begin{array}{r}1.00 \\
1.47 \\
2.11 \\
12.95 \\
12.94\end{array}$ & $\begin{array}{r}1.14-1.90 \\
1.26-3.55 \\
p=0.002 \\
p<0.001\end{array}$ \\
\hline
\end{tabular}

* Likelihood ratio test.

** Based on the analysis of matched case-control sets.

*** Adjusted for income, education for father and mother, mother's age, and crowding.

Crude and adjusted analyses of the association between the number of children in the home and pneumonia are shown in Table2. Adjustment for confounding included income, education for the father and mother, mother's age and crowding, defined as the mean number of people per room.

There was a significant linear trend $(p<$ 0.006) for the total number of children living at home. Children from families with a total number of 7 or more children were at 2.36 times higher risk of having pneumonia $(\mathrm{Cl}=1.26$, 4.43) compared with the baseline category of 1 and 2 children. Children whose families had between 5 and 6 children and those with 3 and 4 children had an intermediate risk of 1.39 and 1.17 , respectively.

Significant trends also existed when the number of children were divided into those aged under six years living at home and those aged six years or more. Children with two to three siblings under six years and children with 4 or more siblings were at 1.35 and 2.05 times higher risk of having pneumonia, respectively, than those having only one sibling under six years at home. This trend was significant at the $p=0.003$ level. Similarly, there was a highly significant linear trend $(p<0.001)$ for the number of siblings aged six years or more living at home. Children with 4 or more siblings and children with 1 to 3 siblings were at 2.11 and 1.47 times higher risk, respectively, compared to those with no siblings aged six years or more at home.

The crude and adjusted analysis of the presence of siblings under two years of age living at home did not show a statistically significant increased risk of pneumonia (Table 3, $p=0.13)$. The total number of children was also more important than birth order (Table 3). Although there was a trend of increasing risk of pneumonia with higher birth order, children having six or more younger siblings being at 1.32 times the risk of first-born, this was not statistically significant after adjustment for confounding variables ( $p=0.37$ ).

Table 4 shows that a high proportion of cases (29.8\%) and controls (24.0\%) had at least one grand parent living at home, and that this was significantly associated with pneumonia $(\mathrm{OR}=1.40, \mathrm{Cl}=1.03,1.89)$ after adjustment for several confounding variables, including family income, education of the father and mother, mother's age, work by the mother, use of daycare facilities, and crowding.

Although a higher proportion of mothers working outside the house reported having grandparents living at home (34.4\%) compared to mothers working at home $(20.0 \%)$ and to mothers not working (24.2\%), this did not explain the increased risk associated with the presence of grandparents in the house. Only $21 \%$ of the mothers with children attending a day-care center reported grand parents living at home. 
Table 3

N umber of siblings under two years of age living at home and birth order as risk factors for childhood pneumonia.

\begin{tabular}{|c|c|c|c|c|c|c|c|c|c|}
\hline \multirow[t]{3}{*}{ Risk factor } & & & & & & \multicolumn{4}{|c|}{ Odds ratio $(95 \% \mathrm{Cl})$} \\
\hline & & \multicolumn{2}{|c|}{ Cases } & \multicolumn{2}{|c|}{ Controls } & \multicolumn{2}{|c|}{ Unadjusted** } & \multicolumn{2}{|c|}{ Adjusted } \\
\hline & & $\mathrm{n}$ & $\%$ & $\mathrm{n}$ & $\%$ & & & & \\
\hline \multirow{3}{*}{$\begin{array}{l}\text { Number of siblings } \\
\text { under } 2 \text { years of age } \\
\text { living at home }\end{array}$} & None & 533 & 82.0 & 552 & 85.0 & 1.00 & & $1.00^{a}$ & \\
\hline & $1+$ & 117 & 18.0 & 98 & 15.0 & 1.31 & $0.94-1.82$ & 1.30 & $0.93-1.82$ \\
\hline & LRT* (1df) & & & & & 2.53 & $p=0.11$ & 2.31 & $p=0.13$ \\
\hline \multirow[t]{6}{*}{ Birth order } & First born & 173 & 26.8 & 204 & 32.0 & 1.00 & & $1.00^{b}$ & \\
\hline & $2-3$ & 380 & 58.5 & 343 & 52.8 & 1.43 & $1.13-1.82$ & 1.35 & $1.05-1.75$ \\
\hline & $4-5$ & 108 & 16.7 & 106 & 16.6 & 1.23 & $0.87-1.75$ & 1.10 & $0.73-1.67$ \\
\hline & $6+$ & 89 & 13.8 & 70 & 11.0 & 1.53 & $1.03-2.26$ & 1.32 & $0.79-2.22$ \\
\hline & LRT* (3df) & & & & & 5.10 & $p=0.17$ & 1.95 & $p=0.58$ \\
\hline & (trend, 1df) & & & & & 4.23 & $p=0.04$ & 0.96 & $p=0.37$ \\
\hline
\end{tabular}

* Likelihood ratio test.

** Based on the analysis of matched case-control sets.

[a] Adjusted for income, education for father and mother, mother's age, and crowding.

[b] Adjusted for income, education for father and mother, mother's age, number of children living in the home, work by mother, use of day-care facilities, and crowding.

Table 4

Presence of grandparents in the house as risk factors for childhood pneumonia.

\begin{tabular}{|c|c|c|c|c|c|c|c|c|}
\hline \multirow[t]{3}{*}{ Risk factor } & & & & & & \multicolumn{3}{|c|}{ Odds ratio $(95 \% \mathrm{Cl})$} \\
\hline & & \multicolumn{2}{|c|}{ Cases } & \multicolumn{2}{|c|}{ Controls } & Unadjusted $* *$ & \multicolumn{2}{|c|}{ Adjusted*** } \\
\hline & & $\mathrm{n}$ & $\%$ & $\mathrm{n}$ & $\%$ & & & \\
\hline Grandparents & No & 456 & 70.2 & 494 & 76.0 & 1.00 & 1.00 & \\
\hline \multirow[t]{2}{*}{ living in the home } & Yes & 194 & 29.8 & 156 & 24.0 & $1.07-1.80$ & 1.40 & $1.03-1.89$ \\
\hline & LRT* $^{*}(\mathrm{dff})$ & & & & & $p=0.01$ & 4.68 & $p=0.03$ \\
\hline
\end{tabular}

* Likelihood ratio test.

** Based on the analysis of matched case-control sets.

*** Adjusted for income, education for father and mother, mother's age, number of children living in the home, work by mother, use of day-care facilities, and crowding.

\section{Discussion}

This paper examines the relationship between several variables related to child care and an increased risk of pneumonia. We found that mother's paid employment outside the house was independently associated with the occurrence of pneumonia after controlling for several socioeconomic variables. This is in agreement with two recent studies carried out in South America which also found that children of mothers working outside the home were at higher risk of acute lower respiratory infection. However, neither of these studies included adjustment for confounding variables (Cerqueiro et al., 1990; Hortal et al., 1990). We also found that children whose mothers had worked $75 \%$ or more of the time since the child was born were at 1.76 $(\mathrm{Cl}=1.13,2.73)$ times higher risk of pneumonia than those whose mothers did not work.
It has been suggested by others that the neglect of a young child during the mother's working hours may be a factor predisposing to malnutrition (Engle, 1991; Engle \& Pedersen, 1989) and respiratory infection (Reichenhein \& Harpham, 1989). It is also known that the stress and anxiety for both mother and child affect the child's immune function (Graham, 1990). Thus, both stress and inappropriate child-care practices may have an important role in increasing the risk of pneumonia in young children.

Attendance at a day care center was found to be strongly associated with pneumonia, with an increased risk of more than 5 , after controlling for income and parental level of education. A recent case-control study investigated risk factors for radiologically confirmed pneumonia in the greater metropolitan area of Porto Alegre, in Southern Brasil. Day-care center attendance displayed the highest risk, with an 
adjusted odds ratio of 11.75 (Victora et al., 1994). These are the first two studies from a developing country to investigate this association. Most of the previous studies on day-care center attendance were carried out in developed countries and focused on upper respiratory infections (Haskins \& Kotch, 1986). A casecontrol study carried out in the USA reported that risk of hospitalization for ALRI tripled for children attending day-care centers compared to those who did not, after controlling for confounding (Anderson et al., 1988).

In theory, a well-managed setting should not increase the risk of severe respiratory infection in a healthy child (Haskins \& Kotch, 1986). However, poor quality of care which deprives a child of stimulation and affection in association with increased exposure to respiratory pathogens and inappropriate feeding practices might lead to an increased risk of severe diseases such as pneumonia.

In our study population, most of the children came from very poor families, and a high proportion of those attending day-care centers (80\%) had mothers working outside the house to supplement the family income. The number of children attending day-care facilities in the State of Ceará is increasing, and the local government has decided to double the number of publicly funded centers in the next three years. Thus, information on possible ways in which day-care centers might be designed and managed to minimize the risk of pneumonia is urgently needed.

Having many siblings increased the risk of pneumonia, after controlling for socioeconomic variables, mother's age, and crowding. Having seven or more siblings living at home more than doubled the risk of pneumonia. This is in agreement with findings from previous studies from both developed and developing countries (Cerqueiro et al., 1990; Gardner et al., 1984; Leeder et al., 1976). It has been suggested that the presence of other young children may cause earlier and more intense exposure to respiratory pathogens (Victora et al., 1989). This might lead to an increased risk of a severe episode of respiratory infection in children, especially among those with malnutrition (Riley, 1984).

The study results are consistent with the hypothesis that factors related to child care may have an important role in the occurrence of pneumonia in children. There is a small proportion of children (less than 5\%) attending day-care facilities when compared to the proportion of mothers in paid employment (more than $30 \%$ ). It is common practice in Fortaleza (Fonseca et al., 1994) as well as in other devel- oping countries besides Brazil (Cerqueiro et al., 1990) to have grandparents and/ or older siblings taking care of younger children when the mother is away from home. Both presence of grandparents and that of children over six years of age were found to be independent risk factors for pneumonia. This is in agreement with findings from previous studies on ALRI from developing countries (Cerqueiro et al., 1990). It is important to note that presence of grandparents was found to be associated with pneumonia, after controlling for several confounding variables, including crowding. This could represent some behavioral characteristic of extended families associated with late health (care-seeking).

After controlling for several confounding variables, having a younger sibling or being late in birth order were not associated with the occurrence of pneumonia.

In summary, this study has highlighted the possible contribution of child-care practices to the risk of childhood pneumonia. The mechanisms by which these factors may affect a child's health require further study. ParticularIy necessary is information regarding cultural perceptions and concepts of care-giving and maternal management of home activities (Pelto et al., 1996). 


\section{References}

AHRTAG (Appropriate Health Resources and Technology Action Group), 1991. Childhood pneumonia; strategies to meet the challenge. In: Proceedings of the International Consultation on Acute Respiratory Infections, December 11-13, 1991, Washington, DC. London: Appropriate Health Resources and Technology Action Group.

ANDERSON, L. J.; PARKER, R. A.; RAYMOND, A. S.; FARRAT, J. A.; GANGAROSA, E. J.; KEYSERLING, H. L. \& SI KES, R. K., 1988. Day-care center attendance and hospitalization for lower respiratory tract illness. Pediatrics, 82:300-308.

CAMPBELL, H.; BYASS, P.; LAMONT, A. C.; FORGIE, I. M.; O'NEIL, K. P.; LLOYD-EVANS, N. \& GREENWOOD, B. M., 1989. Assessment of clinical criteria for identification of severe acute lower respiratory infection, Lancet, 1:297-299.

CERQUEIRO, M. C.; MURTAGH, P.; HALAC, A.; AVILA, M. \& WEISSENBACHER, M., 1990. Epidemiologic risk factors for children with acute lower respiratory tract infection in Buenos Aires, Argentina: a matched case-control study. Reviews of Infectious Diseases, 12(suppl):1021-1027.

CHANDRA, R. K., 1991. McCollum Award Lecture. Nutrition and immunity: lessons from the past and new insights into the future. American Journal of Clinical Nutrition, 53:1087-1101.

ENGLE, P. L., 1990. Care and Nutrition: ICN Theme Paper. UNICEF. New York, U.S.A. (mimeo.)

ENGLE, P. L., 1991. Maternal work and child-care strategies in peri-urban Guatemala: nutritional effects. Child Devel opment, 62:954-965.

ENGLE, P. L. \& PEDERSEN, M. E., 1989. Maternal work for earning and children's nutritional status in urban Guatemala. Ecology of Food and Nutrition, 22:211-223.

FONSECA, W.; KIRKWOOD, B.; VICTORA, C. G.; FUCHS, S. R.; FLORES, J. A. \& MISAGO, C., 1996. Risk factors for childhood pneumonia among the urban poor in Fortaleza, Brazil: a case-control study. Bulletin of theWorld Health Organization. (in press)

FONSECA, W.; MISAGO, C. \& NATIONS, M., 1994. Mothers' perception of pneumonia in Fortaleza, Brazil. (unpublished)

GARDNER, G.; FRANK, A. L. \&TABER, L. H., 1984. Effects of social and family factors on viral respiratory infections and illness in the first year of life. Journal of Epidemiology and Community Health, 38:42-48.

GRAHAM, N. M. H., 1990. The epidemiology of acute respiratory infections in children and adults: a global perspective. Epidemiologic Reviews, 12: 149-178.

HASKINS, R. \& KOTCH, J., 1986. Day care and illness: evidence, cost, and public policy. Pediatrics, 77(suppl):951-982.
HORTAL, M.; BENITEZ, A.; CONTERA, M.; ETORENA, P.; MONTANO, A. \& MENY, D. A., 1990. Community-based study of acute respiratory tract infections in children in Uruguay. Reviews of Infectious Diseases, 12(suppl):966-973.

KIRKWOOD, B. R., 1988. Essentials of Medical Statistics. Oxford: Blackwell Scientific Publication.

LEEDER, S.; CORKHILL, R.; IRWING, L. M., 1976. Influence of family factors in the incidence of lower respiratory illness during the first year of life. British Journal of Preventive and Social Medicine, 30:203-212.

PELTO, G. H.; CAPACCHIONE, C. M.; LINDSAY, H. A.; BACKSTRAND, J. R.; CHAVEZ, A. \& MENESES, L., 1996. Maternal household management and children's size in rural Mexico. Social Scienceand Medicine. (in press)

PELTO, H. G.; KENDALL, C., 1990.Behavioral aspects of acute respiratory infection in children. In: AL$\mathrm{RI}$ and Child Survival in Developing Countries, pp.145-151. Baltimore: Ed. Anne Gadomski. The Johns Hopkins University.

REICHENHEIM, M. \& HARPHAM, T., 1989. Child health in a Brazilian squatter settlement: acute infections and associated risk factors. Journal of Tropical Pediatrics, 35:315-320.

RILEY, I., 1984. The aetiology of acute respiratory infections in children in developing countries. Proceedings of an International Workshop, pp. 33-41. Sydney: Ed. Douglas RM and Kerby-Eaton E.

RODRIGUES, L.; KIRKWOOD, B. R., 1990. Case-control designs in the study of common diseases: Updates on the demise of the rare disease assumption and the choice of sampling scheme for controls. International Journal of Epidemiology, 19:205-213.

ROTHMAN, K. J., 1986. Modern Epidemiology. Boston: Little, Brown.

SCHLESSELMAN, J. J., 1982. Case-Control Studies: Design, Conduct, Analysis. New York: Oxford University Press.

UNICEF, 1989. A saúde das crianças cearences: um estudo de 8.000 famílias. Fortaleza: UNICEF. (unpublished).

VICTORA, C. G.; FUCHS, S. C.; FLORES, J. A. C.; FONSECA, W. \& KIRKWOOD, B., 1994. Risk factors for pneumonia among children in a Brazilian Metropolitan Area. Pediatrics, 93:977-985.

VICTORA, C. G.; SMITH, P. G.; BARROS, F. C.; VAUGHAN, J. P. \& FUCHS, S. C., 1989. Risk factors for deaths due to respiratory infections among Brazilian Infants. International Journal of Epidemiology, 18:918-925.

WHO (World Health Organization), 1989. Programme for Control of Acute Respi ratory Infections: Programme Report, 1988. Geneva: World Health Organization, WHO/ARI/89.3. 